\title{
Fractalkine (CX3CL1) and brain inflammation: Implications for HIV-1-associated dementia
}

\author{
R Cotter, ${ }^{1,2}$ C Williams, ${ }^{1,2}$ L Ryan, ${ }^{1,2}$ David Erichsen, ${ }^{1,2}$ A Lopez, ${ }^{1,2}$ H Peng, ${ }^{1,2}$ and J Zheng ${ }^{1,2,3}$ \\ ${ }^{1}$ The Laboratory of Neurotoxicology, the Center for Neurovirology and Neurodegenerative Disorders, and the \\ Departments of ${ }^{2}$ Pathology and Microbiology and ${ }^{3}$ Pharmacology, University of Nebraska Medical Center, Omaha, \\ Nebraska, USA
}

\begin{abstract}
Leukocyte migration and activation play an important role in immune surveillance and the pathogenesis of a variety of neurodegenerative disorders, including human immunodeficiency virus (HIV)-1-associated dementia (HAD). A novel chemokine named fractalkine (FKN, CX3CL1), which exists in both membrane-anchored and soluble isoforms, has been proposed to participate in the generation and progression of inflammatory brain disorders. Upon binding to the CX3C receptor one (CX3CR1), FKN induces adhesion, chemoattraction, and activation of leukocytes, including brain macrophages and microglia (MP). Constitutively expressed in the central nervous system (CNS), mainly by neurons, FKN is up-regulated and released in response to proinflammatory stimuli. Importantly, FKN is up-regulated in the brain tissue and cerebrospinal fluid (CSF) of HAD patients. Together, these observations suggest that FKN and its receptor have a unique role in regulating the neuroinflammatory events underlying disease. This review will examine how FKN contributes to the recruitment and activation of CX3CR1-expressing MP, which are critical events in the neuropathogenesis of HAD. Journal of NeuroVirology (2002) 8, 585-598.
\end{abstract}

Keywords: chemokine receptors; chemokines; fractalkine; HIV-1-associated dementia

\section{Introduction}

Human immunodeficiency virus (HIV)-1-associated dementia (HAD) is a late-stage complication of advanced HIV-1 disease (Carpenter et al, 2000; Krebs et al, 2000; McArthur et al, 1999). Clinically, HAD results in a spectrum of neurological and psychiatric symptoms, including cognitive impairment, hallucinations, delirium, coma, and ultimately death (Gelbard and Epstein, 1995; Janssen et al, 1991; Marder et al, 1996; Masliah, 1996; Navia et al, 1986).

Address correspondence to Jialin Zheng, Laboratory of Neurotoxicology, Center for Neurovirology and Neurodegenerative Disorders, 985215 Nebraska Medical Center, Omaha, NE 68198-5215, USA. E-mail: jzheng@unmc.edu

The authors kindly thank Dr. Howard E Gendelman, Mr. Douglas Niemann, and Mr. Michael Bauer for scientific discussion and suggestions; and Ms. Julie Ditter, Ms. Robin Taylor, and Ms. Theresa Grutel for outstanding administrative and secretarial support. This work was supported in part by research grants P20 RR15635-01 and R01 NS 41858-01 from the National Institutes of Health (to JZ).

Received 15 February 2002; revised 13 May 2002; accepted 1 July 2002.
The histopathological correlate of HAD is HIV-1 encephalitis (HIVE), which occurs in most, but not all, cases of dementia related to HIV-1 infection (Glass et al, 1995; Masliah, 1996; Wiley, 1995). HIVE features blood-brain-barrier (BBB) damage, productive viral infection, immune activation of mononuclear phagocytes (MP; brain macrophage and microglia), astrogliosis, and neuronal injury, apoptosis, and loss (Asare et al, 1996; Dickson et al, 1994; Gabuzda and Wang, 1999; Gendelman et al, 1997; Glass et al, 1995; Masliah et al, 2000; McArthur et al, 1999; Nath and Geiger, 1998; Navia et al, 1986; Rappaport et al, 1999; Wiley and Achim, 1994). It is believed that MP, the predominate cell type infected in the brain, induce neuronal injury and death through the production of neurotoxins (Gendelman et al, 1997; Genis et al, 1992; Giulian et al, 1990; Koenig et al, 1986; Ma et al, 1994; Moses et al, 1993; Nath et al, 1995; Pulliam et al, 1991; Ranki et al, 1995; Tornatore et al, 1991; Wiley et al, 1991). Given what is known about the involvement of MP in HIVE, it is important to understand how MP become immune activated. Recently, it has been proposed that neurons may directly participate in the disease process by inducing MP 
recruitment and activation through release of soluble chemotactic factors. This review will examine the role that neuronal chemokines play in MP recruitment and activation during HAD.

\section{Chemokines and chemokine receptors in the CNS}

Chemoattractant cytokines (chemokines) are soluble molecules that regulate the migration and activation of leukocytes into brain and other tissues (Kutsch et al, 2000; Wu et al, 2000). More than 46 chemokines have been identified (Baggiolini et al, 1997; Zlotnik and Yoshie, 2000) and are classified into the following four groups (Table 1): alpha (CXC), beta (CC), gamma (C-chemokines), and delta (CX3C), based on the arrangement of cysteine residues within the receptor-binding domain. For example, CXC chemokines have two cysteine residues separated by a single amino acid, whereas in CC chemokines the cysteines are adjacent. Chemokines exert their effects by binding to and activating a family of seven-transmembrane, G-protein-coupled receptors (GPCRs). These receptors are divided into four groups: $\alpha$-chemokine receptors (CXCR1-6), $\beta$-chemokine receptors (CCR1-10), $\gamma$-chemokine receptors (XCR1), and $\delta$-chemokine receptors (CX3CR1) (Hesselgesser and Horuk, 1999; Klein et al, 1999; van der Meer et al, 2000) (review in Gabuzda et al, 2002; Karpus, 2001; Miller and Meucci, 1999; Ransohoff, 1998). In addition to mediating leukocyte recruitment and activation, chemokine receptors, such as CCR5 and CXCR4, also serve as coreceptors for HIV-1 (Dragic et al, 1996; He et al, 1997). Importantly, the endogenous ligands (RANTES, macrophage inflammatory protein [MIP]-1 $\alpha / \beta$ ) for these receptors have been shown to block HIV-1 binding and entry, suggesting that the production of these factors may be an important defense mechanism against HIV-1 infection in the human host (Kornbluth et al, 1998).

A wide range of chemokines are expressed in the brain during diseases, including $\alpha$-chemokines, such as interleukin-8 (IL-8, CXCL8) and stromal-derived factor-1 alpha (SDF-1 $\alpha$, CXCL12); $\beta$-chemokines, such as monocyte chemoattractant protein (MCP)-1 (CCL2), MIP-1 $\alpha$ (CCL3), MIP-1 $\beta$ (CCL4), and RANTES (CCL5); and the $\delta$-chemokine, fractalkine (FKN, CX3CL1) (Conant et al, 1998; Cotter et al, 1999b; Coughlan et al, 2000; Desbaillets et al, 1994; Gabuzda and Wang, 2000; Kornbluth et al, 1998; Persidsky, 1999; Zheng et al, 1999). Chemokines, such as SDF-1 $\alpha$, IL-8, and fractalkine (FKN), are constitutively produced in the brain and play an important role in central nervous system (CNS) homeostasis and development (Coughlan et al, 2000; Gabuzda and Wang, 2000; Gleichmann et al, 2000; Harrison et al, 1998; Horuk et al, 1996; Meucci et al, 1998, 2000; Nagasawa et al, 1996). Upon binding to neu-
Table 1 Chemokine and chemokine receptor families*

\begin{tabular}{|c|c|c|}
\hline $\begin{array}{c}\text { Systematic } \\
\text { name }\end{array}$ & Human ligand & $\begin{array}{l}\text { Chemokine } \\
\text { receptors }\end{array}$ \\
\hline \multicolumn{3}{|c|}{ Alpha (CXC) chemokine-receptor family } \\
\hline CXCL1 & $\mathrm{GRO} \alpha / \mathrm{MGSA} \alpha$ & CXCR2, CXCR1 \\
\hline CXCL2 & GRO $\beta /$ MGSA $\beta$ & CXCR2 \\
\hline CXCL3 & GRO $\gamma / \mathrm{MGSA} \gamma$ & CXCR2 \\
\hline CXCL4 & $\mathrm{PF} 4$ & Unknown \\
\hline CXCL5 & ENA-78 & CXCR2 \\
\hline CXCL6 & GCP-2 & CXCR1, CXCR2 \\
\hline CXCL7 & NAP-2 & CXCR2 \\
\hline CXCL8 & IL-8 & CXCR1, CXCR2 \\
\hline CXCL9 & Mig & CXCR3 \\
\hline CXCL10 & IP-10 & CXCR3 \\
\hline CXCL11 & I-TAC & CXCR3 \\
\hline CXCL12 & SDF-1 $(\alpha / \beta)$ & CXCR4 \\
\hline CXCL13 & BCA-1 & CXCR5 \\
\hline CXCL14 & BRAK/bolkine & Unknown \\
\hline (CXCL15) & Unknown & Unknown \\
\hline CXCL16 & & CXCR6 \\
\hline \multicolumn{3}{|c|}{ Beta (CC) chemokine-receptor family } \\
\hline CCL1 & I-309 & CCR8 \\
\hline CCL2 & MCP-1/MCAF/TDCF & CCR2 \\
\hline CCL3 & MIP-1 $\alpha /$ LD78 $\alpha$ & CCR1, CCR5 \\
\hline CCL4 & MIP- $1 \beta$ & CCR5 \\
\hline CCL5 & RANTES & CCR1, CCR3, CCR5 \\
\hline (CCL6) & Unknown & Unknown \\
\hline CCL7 & MCP-3 & CCR1, CCR2, CCR3 \\
\hline CCL8 & MCP-2 & CCR3, CCR5 \\
\hline (CCL9/10) & Unknown & CCR1 \\
\hline CCL11 & Eotaxin & CCR3 \\
\hline (CCL12) & Unknown & CCR2 \\
\hline CCL13 & MCP-4 & CCR2, CCR3 \\
\hline CCL14 & HCC-1 & CCR1, CCR5 \\
\hline CCL15 & HCC-2/Lkn-1/MIP-1 $\delta$ & CCR1, CCR3 \\
\hline CCL16 & HCC-4/LEC/LCC-1 & CCR1, CCR2 \\
\hline CCL17 & TARC & CCR4 \\
\hline CCL18 & DC-CK1/PARC/AMAC-1 & Unknown \\
\hline CCL19 & MIP-3 $\beta /$ ELC/exodus-3 & CCR7 \\
\hline CCL20 & MIP-3 $\alpha /$ LARC/exodus-1 & CCR6 \\
\hline CCL21 & 6Ckine/SLC/exodus-2 & CCR7 \\
\hline CCL22 & MDC/STCP-1 & CCR4 \\
\hline CCL23 & MPIF-1/CK $\beta 8 / C K \beta 8-1$ & CCR1 \\
\hline CCL24 & Eotaxin-2/MPIF-2 & CCR3 \\
\hline CCL25 & TECK & CCR9 \\
\hline CCL26 & Eotaxin-3 & CCR3 \\
\hline CCL27 & CTACK/ILC & CCR10 \\
\hline CCL28 & MEC & CCR3/CCR10 \\
\hline \multicolumn{3}{|c|}{ Gamma (C) Chemokine/receptor family } \\
\hline XCL1 & Lymphotactin/SCM-1 $\alpha$ & XCR1 \\
\hline XCL2 & SCM-1 $\beta$ & XCR1 \\
\hline \multicolumn{3}{|c|}{ Delta (CX3C) chemokine/receptor family } \\
\hline CX3CL1 & Fractalkine/neurotactin & CX3CR1 \\
\hline
\end{tabular}

*Modified from Zlotnik and Yoshie (2000).

ronal receptors (CXCR4, CXCR2, and CX3CR1), these chemokines activate signaling pathways that regulate neuronal survival, injury, and repair (Kaul and Lipton, 1999; Meucci et al, 1998, 2000; Peng et al, 2002; Tong et al, 2000; Zheng et al, 2001). For example, knockout mice lacking CXCR4 exhibit abnormal migration of cerebellar external granule layer cells and other nervous system defects (Zou et al, 1998). These findings underscore the importance of chemokines and their receptors in neuronal cell development and maintenance. 
Chemokines also play a critical role in the host response to CNS injury and infection. Indeed, the role of chemokines and their receptors in neurodegenerative disorders, such as multiple sclerosis, Alzheimer's disease, stroke, and HAD, has been extensively investigated and reviewed (Gabuzda et al, 1998, 2002; Karpus, 2001; Letendre et al, 1999; Minami and Satoh, 2000; Ransohoff, 1997; Sanders et al, 1998). Several reports have shown that SDF-1 $\alpha$, IL-8, MIP- $1 \alpha$, MIP-1 $\beta$, RANTES, MCP-1, and FKN are up-regulated in brain tissue and cerebrospinal fluid (CSF) from HAD patients (Coughlan et al, 2000; Kelder et al, 1998; Persidsky et al, 1999; Tong et al, 2000; Zheng et al, 1999, 2000). It has been proposed that these chemokines contribute to HAD pathogenesis through recruitment of monocytes into the brain, through initiation of neuroinflammatory cascades that affect viral replication, through induction of neural signaling and apoptosis, or through initiation of neuronal protection and repair (Albright et al, 1999; Broder and Collman, 1997; Cotter et al, 2001; Endres et al, 1996; Ghorpade et al, 1998; He et al, 1997; Kitai et al, 2000; Lavi et al, 1997; Luster, 1998; Mackay, 1996; Shieh et al, 1998; Vallat et al, 1998; Vicenzi et al, 2000; Zheng et al, 1999) (review in Gabuzda et al, 2002; Miller and Meucci, 1999). Although it is evident that chemokines are an important component of the host immune response, the nature of their role in disease pathogenesis is only beginning to be understood.

\section{Neuronal chemokines and MP activation, a "chicken or egg" question}

Traditionally, it was believed that MP activation and chemokine production preceded neuronal injury in HIVE. However, new evidence suggests that neurons themselves may initiate MP recruitment and activation (Biber et al, 2001; Harrison et al, 1998). Indeed, it has been proposed that in response to injury, neurons produce chemokines, such as FKN (Harrison et al, 1998), that act as "distress signals." Upon release, these factors recruit MP to sites of injury and stimulate the production of inflammatory factors with the potential to repair or exacerbate neuronal damage (Tong et al, 2000; Zheng et al, 2000) (Figure 1).

There are several lines of evidence that provide support for this hypothesis. First, excitotoxinmediated neuronal injury, as well as nerve axotomy, induces production of the neuronal chemokine FKN (Chapman et al, 2000a; Harrison et al, 1998; Zheng et al, 2000). Second, this neuronal chemokine is also up-regulated in HAD brain tissue (Pereira et al, 2001; Tong et al, 2000; Zheng et al, 2000) and released in response to neuronal apoptosis induced by HIV-1 progeny virions (IIIB and ADA) and gp120 (Zheng et al, 2000). Third, both the soluble and membranebound forms of FKN have been shown to attract and immobilize leukocytes, such as monocytes and lym- phocytes (Boehme et al, 2000; Chapman et al, 2000a, 2000b; Combadiere et al, 1998; Dorf et al, 2000; Fong et al, 1998; Goda et al, 2000; Harrison et al, 1998; Imai et al, 1997; Tong et al, 2000). The monocytes, when recruited to the site of injury, could secrete other chemokines that recruit additional leukocytes to the site of tissue injury and induce inflammation. Indeed, the FKN-CX3CR1 pair may participate in the generation and progression of inflammatory disorders within the brain and periphery. FKN has already been shown to play a role in a variety of pathological conditions related to inflammation, including atherosclerosis (Alexander, 2001; Greaves and Gordon, 2001; Greaves et al, 2001; McDermott et al, 2001), renal inflammation (Cockwell et al, 2002; Feng et al, 1999; Furuichi et al, 2001), airway inflammation (Fujimoto et al, 2001), psoriasis (Raychaudhuri et al, 2001), arthritis (Ruth et al, 2001; Volin et al, 2001), cardiac allograft rejection (Haskell et al, 2001), progression of acquired immunodeficiency syndrome (AIDS) (Faure et al, 2000; Foussat et al, 2001), and CNS inflammation (Boehme et al, 2000; Harrison et al, 1998; Hughes et al, 2002; Maciejewski-Lenoir et al, 1999; Nishiyori et al, 1998; Schwaeble et al, 1998; Zujovic et al, 2000). These observations suggest that FKN and its receptor have a unique role in regulation of the host response to disease (Fong et al, 1998; Harrison et al, 1998).

The balance of data demonstrates overwhelming support for FKN mediated recruitment of leukocytes. However, studies with FKN and CX3CR1 knockout mice (Cook et al, 2001; Jung et al, 2000) have tempered the importance of FKN and CX3CR1 in leukocyte recruitment. In studies (Cook et al, 2001) with FKN-deficient mice, responses to a variety of inflammatory stimuli were indistinguishable from those of wild-type mice in an intestine inflammation model system (Cook et al, 2001). In other reports (Jung et al, 2000), the absence of CX3CR1 did not interfere with either monocyte extravasation or dendritic cell migration and differentiation in a peritonitis model. Further, CX3CR1-deficient microglia exhibited proficient responses to peripheral nerve injury, indicating unimpaired neuronal-glial cross-talk in the absence of CX3CR1 (Jung et al, 2000). These findings suggest that other means of neuronal-glial linkage exist. Nevertheless, to elucidate the exact role of FKNand CX3CR1-expressing cells in disease pathogenesis, further studies are certainly required. Moreover, FKN-CX3CR1 interactions may mediate other inflammatory responses besides the recruitment of leukocytes. The following section will examine how FKN mediates communication between neurons and MP during homeostasis and disease.

\section{FKN expression, structure, and regulation}

FKN (neurotactin, CX3CL1) is a 373-amino acid, multidomain molecule found in a wide variety of tissues, including liver, intestine, kidney, and brain. 


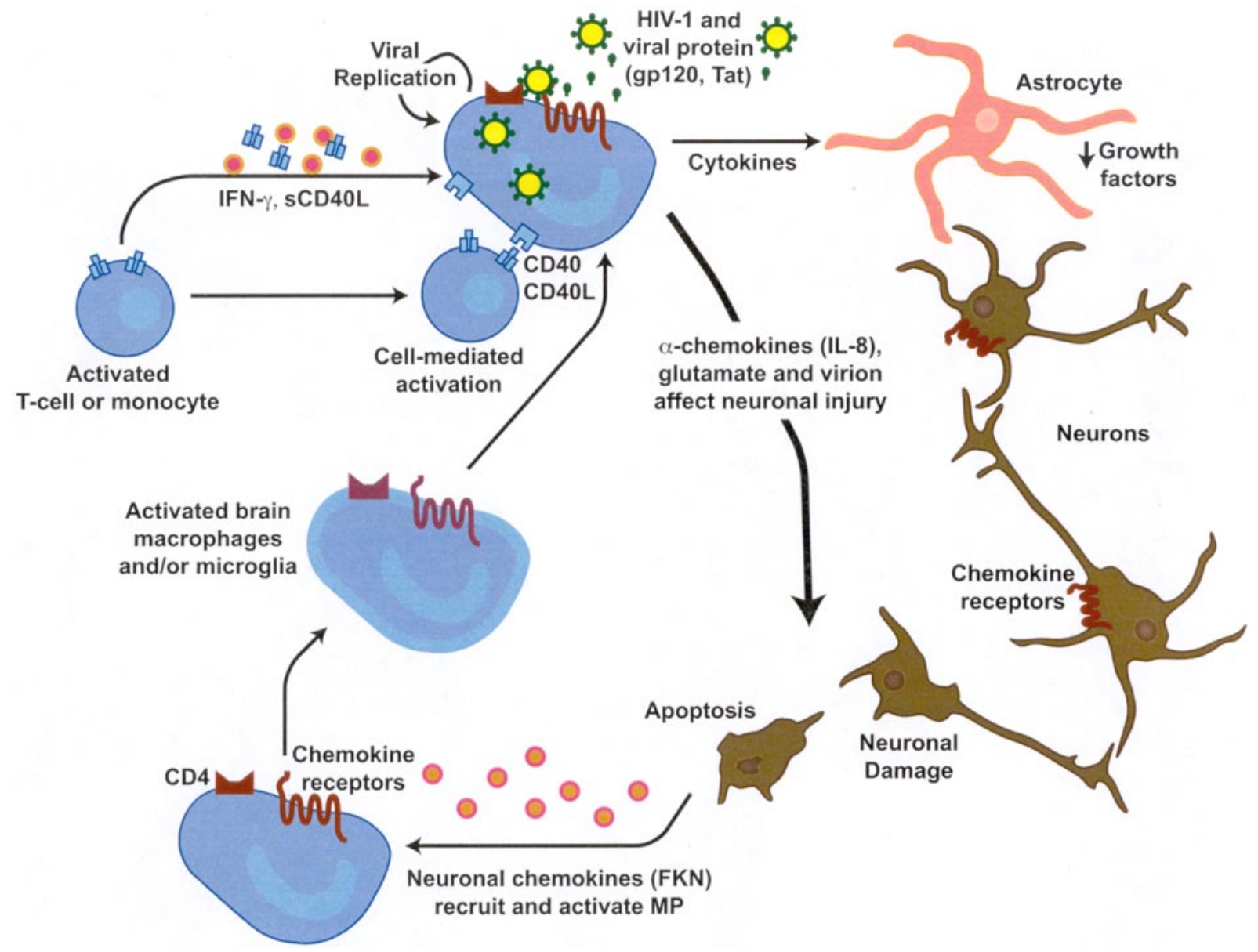

Figure 1 A proposed pathophysiological mechanism for how MP activation influences neuronal injury in HAD. During monocyte/macrophage maturation, macrophages acquire the ability to sustain productive HIV-1 infection. Release of progeny virion leads to infection of resident brain microglia. Uninfected or virus-infected MP can be immune-activated by a process that remains incompletely understood, but likely involves cytokines, chemokines, and cell-to-cell interactions. Released from injured neurons, the neuronal chemokine fractalkine (FKN) represents one pathway through which MP activation may occur. After recruiting MP to the site of injury, FKN may activate MP to produce neurotrophic/toxic factors that affect neuronal survival and induce CNS inflammation. In turn, recruited MP may also become infected and activation leading to the production of chemokines, cytokines, and glutamate. Chemokines, gp120, and whole virions may also interact with neuronal receptors to alter intracellular signal transduction pathways, leading to neuronal dysfunction and death.

Structural components of FKN include a 76-amino acid chemokine domain (CD) at the N-terminus, which is important in the binding, adhesion, and activation of its target cells (Harrison et al, 2001; Mizoue et al, 1999, 2001; Goda et al, 2000; Haskell et al, 2000). In addition, FKN has a 241-amino acid mucin-like stalk, which extends the chemokine domain away from the cell surface in order to aid in the adherence of CX3CR1-expressing cells (Fong et al, 2000). FKN also has an 18-amino acid stretch of hydrophobic residues that spans the cell membrane, and an extended C-terminus that anchors it to the cell surface (Cook et al, 2001; Hoover et al, 2000; Lucas et al, 2001). These unique structural features enable FKN to mediate chemotaxis, adherence, and activation of CX3CR1-expressing cells.

FKN is novel in that it is the only chemokine known to be expressed at higher levels within the CNS than in the periphery (Bazan et al, 1997). In the CNS, FKN is constitutively expressed by neurons (Harrison et al, 1998; Hughes et al, 2002) (Figure 2) and can be induced by astrocytes (Hughes et al, 2002; Pereira et al, 2001; Zheng et al, 2002). It is upregulated and released in response to proinflammatory stimuli, such as lipopolysaccharide (LPS), IL-1 $\beta$, tumor necrosis factor (TNF)- $\alpha$, CD40L, and interferon (IFN)- $\gamma$ (Fraticelli et al, 2001; Fujimoto et al, 2001; Garcia et al, 2000; Hughes et al, 2002; Imaizumi et al, 2000; Pereira et al, 2001; Yoshida et al, 2001; Zheng et al, 2002). This up-regulation is believed to occur through activation of nuclear factor (NF)- $\kappa$ B (Garcia et al, 2000).

FKN is also distinct from other chemokines, because it exists in both membrane-bound and soluble isoforms (Fong et al, 2000; Harrison et al, 2001; Mizoue et al, 2001). In response to excitotoxic stimuli, the membrane-spanning domain is rapidly cleaved and a soluble form of FKN is released from 

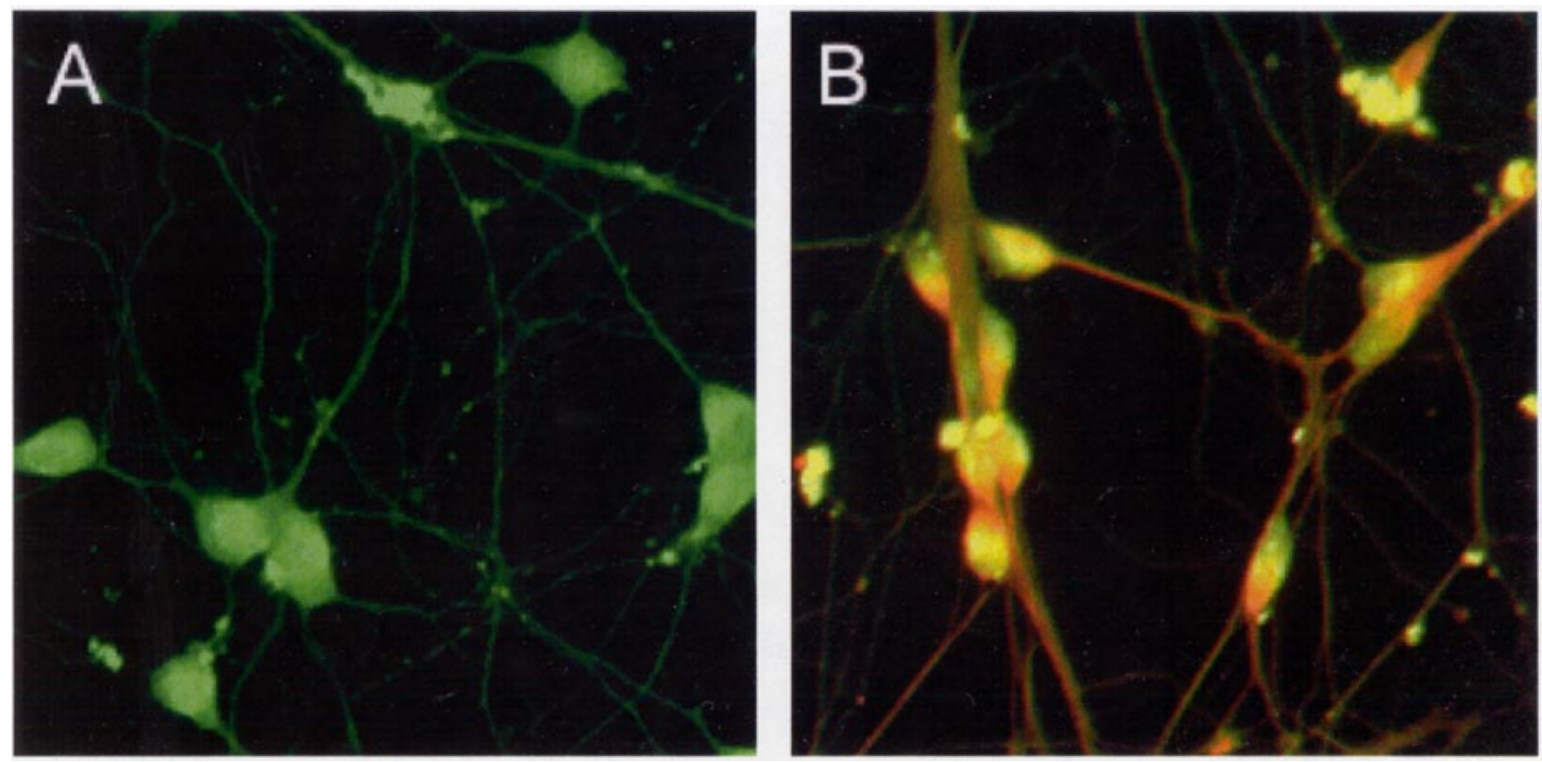

Figure 2 FKN expression in human neuronal cells. Panel (A) shows mixed human cortical cells in culture that were stained for FKN (green) and panel (B) shows neurons double-stained for FKN and MAP-2 (yellow, neuronal marker) (200×). Results are representative of three independent experiments.

the neuronal cell surface (Chapman et al, 2000a; Zheng et al, 2000). Proteolytic cleavage of FKN is proposed to occur at a di-arginine sequence located next to the transmembrane domain (Bazan et al, 1997; Cook et al, 2001; Fong et al, 2000; Harrison et al, 1998, 2001). However, the exact location of the cleavage site remains to be confirmed (Tsou et al, 2001). FKN cleavage can be mediated by two distinct metalloproteinase-dependent activities: a constitutive FKN sheddase, which is active under normal cell culture conditions, and an inducible FKN sheddase that can be rapidly activated by phorbol esters, such as phorbol 12-myristate 13-acetate (PMA) (Garton et al, 2001; Tsou et al, 2001). Recently, inducible cleavage has been shown to be mediated by the TNF- $\alpha$-converting enzyme (TACE), which belongs to a family of proteins containing a metalloprotease domain (Garton et al, 2001; Tsou et al, 2001).

The receptor for FKN, CX3CR1 (Combadiere et al, 1998), is expressed on monocytes (Cambien et al, 2001; Chapman et al, 2000b), dendritic cells (Dichmann et al, 2001), T lymphocytes (Fong et al, 1998; Foussat et al, 2000; Fraticelli et al, 2001), natural killer cells (Fong et al, 1998; Imai et al, 1997; Inngjerdingen et al, 2001), astrocytes (Dorf et al, 2000), neurons (Hughes et al, 2002; Meucci et al, 2000; Tong et al, 2000), and brain microglia (Boehme et al, 2000; Chapman et al, 2000a; Harrison et al, 1998; Hughes et al, 2002). Like other chemokine receptors, CX3CR1 (previously called V28) belongs to a family of GPCRs, which feature a seventransmembrane domain, an extracellular N-terminus, and a cytoplasmic C-terminus. GPCRs interact with and signal through heterotrimeric guanine nucleotide-binding regulatory proteins (G-proteins).
Upon stimulation by a ligand, GPCRs undergo a conformational change that leads to activation of the G-protein by GDP-GTP exchange, followed by uncoupling of the G-protein from the receptor. Upon activation, G-proteins trigger a cascade of signaling events that regulate various cellular functions (Devi, 2000).

\section{FKN functions: Cell adhesion and neuroprotection}

In the brain, FKN is believed to regulate a complex network of paracrine and autocrine interactions between neurons and surrounding MP (Boehme et al, 2000; Harrison et al, 1998; Maciejewski-Lenoir et al, 1999), primarily through chemoattraction and adhesion. Both the soluble and membrane-bound forms of FKN are potent inducers of chemotaxis (Harrison et al, 2001). However, it is the membrane-bound form that enables FKN to immobilize CX3CR1-expressing cells, such as leukocytes (Boehme et al, 2000; Chapman et al, 2000a, 2000b; Combadiere et al, 1998; Dorf et al, 2000; Fong et al, 1998; Harrison et al, 1998; Imai et al, 1997; Tong et al, 2000). Mutation analyses and knockout mouse experiments have shown that specific residues within the FKN CD, such as Lys-7 and Arg-47, are important determinants in mediating binding, signaling, and adhesion of CX3CR1expressing cells (Goda et al, 2000; Harrison et al, 2001; Haskell et al, 2000; Mizoue et al, 1999, 2001). Further, the adherence of FKN to CX3CR1-expressing leukocytes is believed to be integrin independent (Fong et al, 1998). Other studies suggest that adhesion of CX3CR1-expressing leukocytes is independent of G-protein activation (Haskell et al, 1999). It is 
possible that the mucin-like domain of FKN may aid in adherence of CX3CR1-expression cells by extending the chemokine domain away from the cell surface in order to present it to trafficking leukocytes (Fong et al, 2000). Additionally, it is possible that the ability of FKN to mediate adhesion of trafficking cells may be a function of its slow receptor off-rate (Haskell et al, 2000). Nevertheless, it is clear that FKN and CX3CR1 fulfill important roles in leukocyte trafficking.

In addition to chemoattraction and adhesion, FKN may serve other functions, such as inhibition of HIV-1 infection and neuroprotection (Fong et al, 1998; Harrison et al, 1998; Haskell et al, 2000; Inngjerdingen et al, 2001; Tong et al, 2000). For example, FKN inhibits HIV-1 entry into CX3CR1expressing cells (Faure et al, 2000) and inhibits neuronal injury induced by gp120 (Meucci et al, 2000), platelet-activating factor (PAF), and the regulatory HIV-1 gene product, Tat (Tong et al, 2000). FKN has also been shown to inhibit Fas-mediated death in microglia (Boehme et al, 2000). The protective functions of FKN are believed to be mediated through activation of signaling pathways involving the protein kinase, Akt (protein kinase B), and NF- $\kappa$ B, which are major components of prosurvival signaling pathways in neurons and microglia (Boehme et al, 2000; Meucci et al, 2000).

\section{FKN and macrophage activation: Dysregulation of neurotrophic/toxic factors?}

Because CX3CR1 is highly expressed on MP, it is possible that FKN-CX3CR1 interactions play an important role in mediating MP immune activation. Upon binding to CX3CR1, FKN has been shown to stimulate TNF- $\alpha$ and IL-8 production in MP (Figure 3) (Zheng et al, 2002; Zujovic et al, 2000). Although many of the individual factors secreted by FKN-activated MP remain to be determined, it is known that HIV-1infected and immune-activated MP are capable of producing a wide variety of toxic factors. These factors include proinflammatory cytokines such as
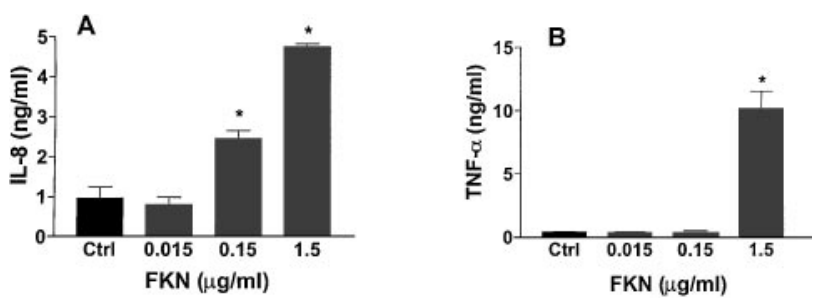

Figure 3 IL-8 (A) and TNF- $\alpha$ (B) production in cell supernatants from FKN-treated human monocyte-derived macrophages (MDM). After 14 days in culture, elutriated and recombinant human macrophage colony-stimulating factor (MCSF)-differentiated human MDM were treated with different concentrations of soluble FKN for 4 h. ${ }^{*} P<.01$ as compared to control. Results are expressed as an average $\pm S D$ and are representative of three independent experiments.
TNF- $\alpha$, IL-1 $\beta$ (Sebire et al, 1993), glutamate (Jiang et al, 2001), arachidonic acid and its metabolites (Genis et al, 1992), PAF (Gelbard et al, 1994), quinolinic acid (Heyes et al, 1991; Kerr et al, 1998), NTox (Giulian et al, 1996), nitric oxide (NO) (Adamson et al, 1996), and reactive oxygen species (ROS) (Mollace et al, 2001). Alternatively, viral infection and FKN-mediated activation of MP may regulate production of trophic factors that mediate neuronal growth and repair (Lopez et al, 2001). A number of neurotrophic factors are secreted by MP (Barnea et al, 1996; Elkabes et al, 1996), including brainderived neurotrophic factor (BDNF) (Kerschensteiner et al, 1999; Miwa et al, 1997), $\beta$-nerve growth factor ( $\beta$ NGF) (Caroleo et al, 2001; Garaci et al, 1999; Lopez et al, 2001), transforming growth factor-beta (TGF- $\beta$ ) (Chao et al, 1995), neurotrophin-3 (NT3) (Kullander et al, 1997; Loy et al, 1994; Mallat et al, 1989; Rocamora et al, 1996; Saad et al, 1991), and glialderived neurotrophic factor (GDNF) (Batchelor et al, 1999). Withdrawal or dysregulation of these factors can result in neuronal injury and death (Deshmukh et al, 1996). Through enhanced neurotoxin secretion and dysregulated neurotrophin production, HIV-1infected and FKN-activated MP may induce neuronal injury and death in HIVE (Aquaro et al, 2000; Conant et al, 1998; Cotter et al, 1999a; Fischer-Smith et al, 2001; Gabuzda et al, 1998; Gendelman, 1997; Glass et al, 1995; Koenig et al, 1986; Lopez et al, 2001; Nath and Geiger, 1998; Perno et al, 1997; Strizki et al, 1996; Wiley et al, 1986; Zheng and Gendelman, 1997).

FKN-induced secretory factor production is believed to occur through activation of intracellular signaling pathways (Cambien et al, 2001; Zheng et al, 2002). Therefore, the following section will discuss the relevant intracellular signaling pathways resulting from FKN-mediated activation of CX3CR1 expressing-MP.

\section{FKN-mediated signal transduction pathways}

Binding of FKN to CX3CR1 on MP initiates multiple signal transduction pathways and leads to the activation of a wide variety of protein kinases, including the tyrosine kinases (the Src tyrosine kinase family and Syk tyrosine kinase family), calcium calmodulin kinase (CaMK), protein kinase C (PKC), phosphatidylinositide 3-kinase (PI 3-kinase), protein kinase $\mathrm{B}$, mitogen-activated protein kinases (MAP kinases), and $\mathrm{NF}-\kappa \mathrm{B}$ (Cambien et al, 2001; Garcia et al, 2000). Activation of these signal transduction pathways leads to elevation of cytosolic free calcium and modifications in enzymes, ion channels, transcriptional activators, and transcriptional regulators (Cambien et al, 2001; Iismaa et al, 1995).

Several studies have shown that binding of FKN to CX3CR1 induces the activation of MAP kinases (Figure 4) (Cambien et al, 2001; Zheng et al, 2002). Activation of MAP kinase pathways stimulate 


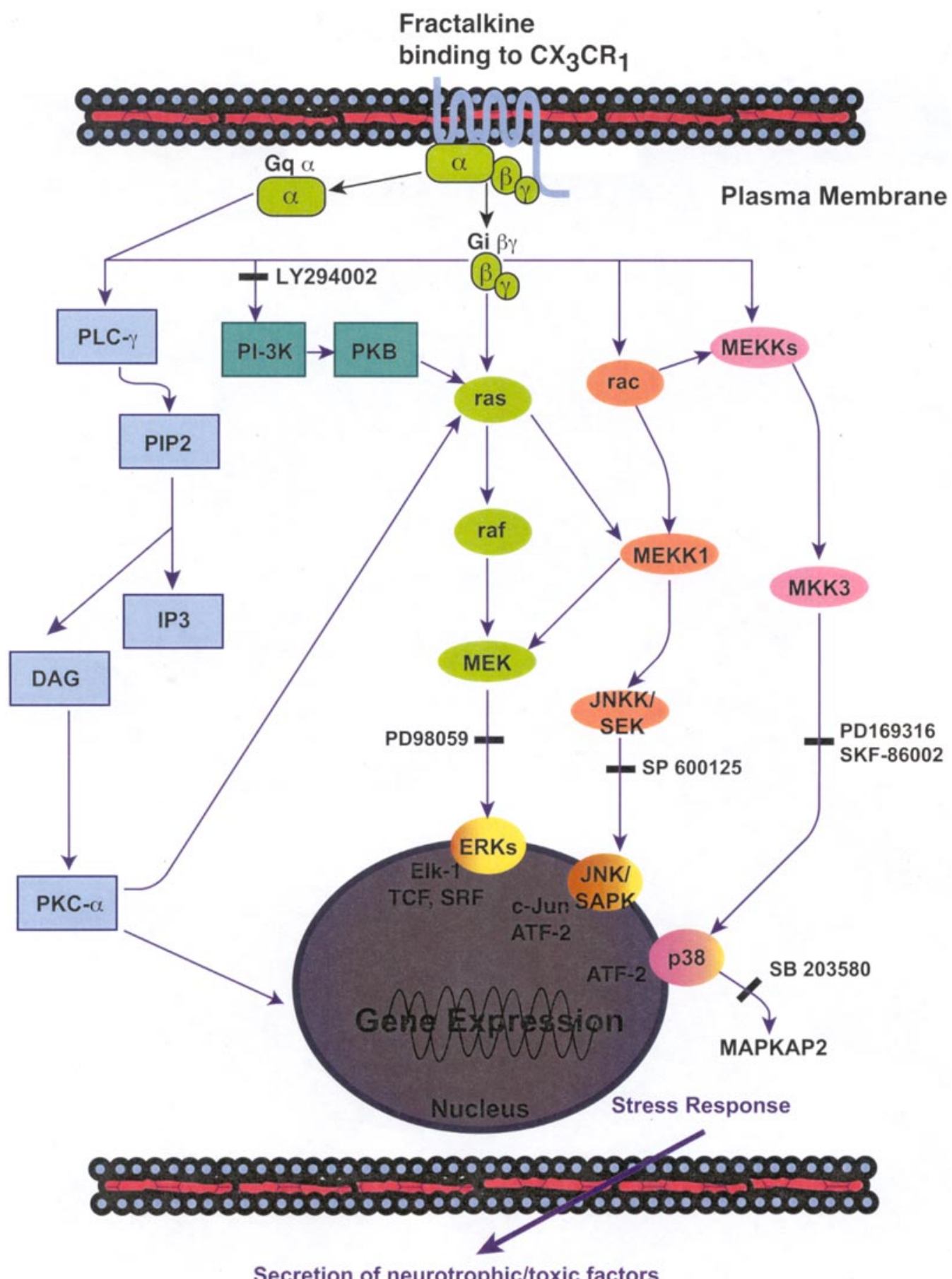

Figure 4 Overview of proposed MAP kinase and protein kinases B and C signal transduction events in mononuclear phagocyte (MP)mediated production of proinflammatory factors or neurotrophic/toxic factors. FKN can bind the chemokine receptor CX3CR1 on MP and activate MAP kinase signaling through the $\alpha$ or $\beta \gamma$ subunit of G-protein, which can further activate one or more types of MAP kinases. These MAP kinases include extracellular signal-related kinases (ERK1 and ERK2) and stress-activated protein kinases (SAPK1/JNK1 and SAPK2/p38). In addition, FKN can also activate intracellular signaling pathways, such as increasing cytosolic free calcium, activation of phosphatidyl inositol 3-kinase (PI-3K) and protein kinase B (PKB), and alteration of protein kinase C, which further activate MP. This activation causes the production of proinflammatory factors or multiple neurotrophic/toxic factors. The inhibitors for different kinase pathways can be used as tools to elucidate the signaling pathways involved in MP activation events. Some of the stimulation pathways may increase the cellular activation state and cause overproduction of cytokines or neurotoxins, which mediate MP-induced neuronal injury in HAD. 
cell growth and differentiation by regulating gene translation and expression (Lopez-Ilasaca, 1998; Lopez-Illasaca et al, 1997). There are three distinct MAP kinase cascades (Figure 4): c-Jun N-terminal kinase/stress-activated protein kinase (JNK/SAPK), p38 (Lopez-Ilasaca, 1998), and extracellular signalrelated kinases (ERK1/ERK2). The JNK/SAPK pathway is induced by exposure to ultraviolet radiation, heat shock, or inflammatory cytokines. The p38 pathway is activated in response to inflammatory cytokines, endotoxins, and osmotic stress. The ERK pathway is stimulated following binding of extracellular growth factors (for example, epidermal growth factor, EGF) to tyrosine kinase-linked receptors. It appears that each of the three MAP kinase pathways, ERK1/2, p38, and JNK, are activated during the binding of FKN to CX3CR1 on monocytederived macrophages (MDM) (Zheng et al, 2002). Interestingly, production of MIP- $1 \beta$ and IL- 8 by FKNactivated MP can be blocked by MAP kinase inhibitors, such as PD98056 (ERK), SB203850 (p38), and SP600125 (JNK) (Zheng et al, 2002). Activation of MAP kinase signaling appears to be critical for FKN-induced capture, adhesion, and activation of MP (Cambien et al, 2001; Kansra et al, 2001; Zheng et al, 2002). Thus, multiple protein kinases appear to be involved in mediating the effects of FKN upon

\section{References}

Adamson DC, Wildemann B, Sasaki M, Glass JD, McArthur JC, Christov VI, Dawson TM, Dawson VL (1996). Immunologic NO synthase: elevation in severe AIDS dementia and induction by HIV-1 gp41. Science 274: 19171926.

Albright AV, Shieh JT, Itoh T, Lee B, Pleasure D, O'connor MJ, Doms RW, Gonzalez-Scarano F (1999). Microglia express CCR5, CXCR4, and CCR3, but of these, CCR5 is the principal coreceptor for human immunodeficiency virus type 1 dementia isolates. J Virol 73: 205-213.

Alexander RW (2001). Cytokine receptor CX3CR-1 and fractalkine: new factors in the atherosclerosis drama? Circ Res 89: 376-377.

Aquaro S, Panti S, Caroleo MC, Balestra E, Cenci A, Forbici F, Ippolito G, Mastino A, Testi R, Mollace V, et al (2000). Primary macrophages infected by human immunodeficiency virus trigger CD95-mediated apoptosis of uninfected astrocytes. J Leukoc Biol 68: 429-435.

Asare E, Dunn G, Glass J, McArthur J, Luthert P, Lantos P, Everall I (1996). Neuronal pattern correlates with the severity of human immunodeficiency virus-associated dementia complex. Am J Pathol 148: 31-38.

Baggiolini M, Dewald B, Moser B (1997). Human chemokines: an update. Annu Rev Immunol 15: 675705.

Barnea A, Aguila-Mansilla N, Chute HT, Welcher AA (1996). Comparison of neurotrophin regulation of human and rat neuropeptide Y (NPY) neurons: induction of NPY production in aggregate cultures derived from rat but not from human fetal brains. Brain Res 732: $52-60$. its target cells. The elucidation of specific pathways through which FKN induces MP activation and regulates production of neurotrophic/toxic factors will be critical to understanding disease pathogenesis in HAD and other neurodegenerative disorders.

\section{Summary}

In summary, the evidence presented within this review suggests that the expression and production of neuronal chemokines, such as FKN, may be a compensatory or reparative response to injury in the brain. As such, we propose that in HAD, viral proteins, such as gp120, induce neuronal injury, leading to the up-regulation or release of FKN. Acting as a "distress signal," FKN may then recruit and activate CX3CR1-expressing MP to the site of injury (Fong et al, 2000; Harrison et al, 2001). Dysregulation of this response may result in further neuronal injury as MP themselves become activated to produce neurotoxins. This, in turn, may induce a cycle of inflammation and injury. Identification of the pathways through which FKN induces MP activation could lead to the development of agents that impede or prevent further neuronal injury in HAD and other neurodegenerative disorders.

Batchelor PE, Liberatore GT, Wong JY, Porritt MJ, Frerichs F, Donnan GA, Howells DW (1999). Activated macrophages and microglia induce dopaminergic sprouting in the injured striatum and express brainderived neurotrophic factor and glial cell line-derived neurotrophic factor. J Neurosci 19: 1708-1716.

Bazan J, Bacon K, Hardiman G, Wang W, Soo K, Rossi D, Greaves D, Zlotnik A, Schall T (1997). A new class of membrane-bound chemokine with a CX3C motif. Nature 385: $640-644$.

Biber K, Sauter A, Brouwer N, Copray SC, Boddeke HW (2001). Ischemia-induced neuronal expression of the microglia attracting chemokine secondary lymphoid-tissue chemokine (SLC). Glia 34: 121-133.

Boehme SA, Lio FM, Maciejewski-Lenoir D, Bacon KB, Conlon PJ (2000). The chemokine fractalkine inhibits Fas-mediated cell death of brain microglia. J Immunol 165: 397-403.

Broder CC, Collman RG (1997). Chemokine receptors and HIV. J Leukoc Biol 62: 20-29.

Cambien B, Pomeranz M, Schmid-Antomarchi H, Millet MA, Breittmayer V, Rossi B, Schmid-Alliana A (2001). Signal transduction pathways involved in soluble fractalkine-induced monocytic cell adhesion. Blood 97: 2031-2037.

Caroleo MC, Costa N, Bracci-Laudiero L, Aloe L (2001). Human monocyte/macrophages activated by exposure to LPS overexpress NGF and NGF receptors. J Neuroimmunol 113: 193-201.

Carpenter CC, Cooper DA, Fischl MA, Gatell JM, Gazzard BG, Hammer SM, Hirsch MS, Jacobsen DM, 
Katzenstein DA, Montaner JS, et al (2000). Antiretroviral therapy in adults: updated recommendations of the International AIDS Society-USA Panel. JAMA 283: 381390.

Chao CC, Hu S, Sheng WS, Tsang M, Peterson PK (1995). Tumor necrosis factor- $\alpha$ mediates the release of bioactive transforming growth factor $\beta$ in murine microglial cell cultures. Clin Immunol Immunopathol 77: 358-365.

Chapman GA, Moores K, Harrison D, Campbell CA, Stewart BR, Strijbos PJ (2000a). Fractalkine cleavage from neuronal membranes represents an acute event in the inflammatory response to excitotoxic brain damage. $\mathrm{JNeu}$ rosci (Online) 20: RC87.

Chapman GA, Moores KE, Gohil J, Berkhout TA, Patel L, Green P, Macphee CH, Stewart BR (2000b). The role of fractalkine in the recruitment of monocytes to the endothelium. Eur J Pharmacol 392: 189-195.

Cockwell P, Chakravorty SJ, Girdlestone J, Savage CO (2002). Fractalkine expression in human renal inflammation. J Pathol 196: 85-90.

Combadiere C, Salzwedel K, Smith ED, Tiffany HL, Berger EA, Murphy PM (1998). Identification of CX3CR1. A chemotactic receptor for the human CX3C chemokine fractalkine and a fusion coreceptor for HIV-1. J Biol Chem 273: 23799-23804.

Conant K, Garzino-Demo A, Nath A, McArthur JC, Halliday W, Power C, Gallo RC, Major EO (1998). Induction of monocyte chemoattractant protein-1 in HIV-1 Tatstimulated astrocytes and elevation in AIDS dementia. Proc Natl Acad Sci USA 95: 3117-3121.

Cook DN, Chen SC, Sullivan LM, Manfra DJ, Wiekowski MT, Prosser DM, Vassileva G, Lira SA (2001). Generation and analysis of mice lacking the chemokine fractalkine. Mol Cell Biol 21: 3159-3165.

Cotter R, Zheng J, Gendelman HE (1999a). The role of mononuclear phagocytes in neurodegenerative disorders: lessons from multiple sclerosis, Alzheimer's disease and HIV-1 dementia. In: Advances in neurodegenerative disorders. Marwah J, Teitelbaum $\mathrm{H}$ (eds). Prominent Press: Scottsdale, AZ, pp 203-241.

Cotter R, Zheng J, Niemann D, Thomas E, Gendelman H (1999b). CD40L activation of mononuclear phagocytes: regulation of HIV-1 replication and beta-chemokine production. Paper presented at XIth International Congress of Virology, Interbational Union of Microbiological Societies, Sydney, Australia, August 9-13.

Cotter RL, Zheng J, Che M, Niemann D, Liu Y, He J, Thomas E, Gendelman HE (2001). Regulation of human immunodeficiency virus type 1 infection, beta chemokine production, and CCR5 expression in CD40L-stimulated macrophages: immune control of viral entry. J Virol 75: 4308-4320.

Coughlan CM, McManus CM, Sharron M, Gao Z, Murphy D, Jaffer S, Choe W, Chen W, Hesselgesser J, Gaylord $\mathrm{H}$, et al (2000). Expression of multiple functional chemokine receptors and monocyte chemoattractant protein-1 in human neurons [In Process Citation]. Neuroscience 97: 591-600.

Desbaillets I, Tada M, de Tribolet N, Diserens AC, Hamou MF, Van Meir EG (1994). Human astrocytomas and glioblastomas express monocyte chemoattractant protein-1 (MCP-1) in vivo and in vitro. Int J Cancer 58: 240-247.

Deshmukh M, Vasilakos J, Deckwerth TL (1996). Genetic and metabolic status of NGF-deprived sympathetic neu- rons saved by an inhibitor of ICE family proteases. J Cell Biol 135: 1341-1354.

Devi LA (2000). G-protein-coupled receptor dimers in the lime light. Trends Pharmacol Sci 21: 324-326.

Dichmann S, Herouy Y, Purlis D, Rheinen H, GebickeHarter P, Norgauer J (2001). Fractalkine induces chemotaxis and actin polymerization in human dendritic cells. Inflamm Res 50: 529-533.

Dickson D, Lee S, Hatch W, Mattiace L, Brosnan C, Lyman W (1994). Macrophages and microglia in HIV-related CNS neuropathology. In: HIV, AIDS, and the brain. Price R, Perry S (eds). Raven: New York, pp 99-118.

Dorf ME, Berman MA, Tanabe S, Heesen M, Luo Y (2000). Astrocytes express functional chemokine receptors. J Neuroimmunol 111: 109-121.

Dragic T, Litwin V, Allaway GP, Martin SR, Huang Y, Nagashima KA, Cayanan C, Maddon PJ, Koup RA, Moore JP, Paxton WA (1996). HIV-1 entry into CD4+ cells is mediated by the chemokines receptor CC-CKR-5. Nature 381: $667-673$.

Elkabes S, DiCicco-Bloom EM, Black IB (1996). Brain microglia/macrophages express neurotrophins that selectively regulate microglial proliferation and function. J Neurosci 16: 2508-2521.

Endres MJ, Clapham PR, Marsh M, Ahuja M, Turner JD, McKnight A, Thomas JF, Stoebenau-Haggarty B, Choe S, Vance PJ, et al (1996). CD4-independent infection by HIV-2 is mediated by fusin/CXCR4. Cell 87: 745-756.

Faure S, Meyer L, Costagliola D, Vaneensberghe C, Genin E, Autran B, Delfraissy JF, McDermott DH, Murphy PM, Debre P, et al (2000). Rapid progression to AIDS in HIV+ individuals with a structural variant of the chemokine receptor CX3CR1. Science 287: 2274-2277.

Feng L, Chen S, Garcia GE, Xia Y, Siani MA, Botti P, Wilson CB, Harrison JK, Bacon KB (1999). Prevention of crescentic glomerulonephritis by immunoneutralization of the fractalkine receptor CX3CR1 rapid communication. Kidney Int 56: 612-620.

Fischer-Smith T, Croul S, Sverstiuk AE, Capini C, L'Heureux D, Regulier EG, Richardson MW, Amini S, Morgello S, Khalili K, Rappaport J (2001). CNS invasion by CD14+/CD16+ peripheral blood-derived monocytes in HIV dementia: perivascular accumulation and reservoir of HIV infection. J NeuroVirol 7: 528-541.

Fong AM, Erickson HP, Zachariah JP, Poon S, Schamberg NJ, Imai T, Patel DD (2000). Ultrastructure and function of the fractalkine mucin domain in $\mathrm{CX}(3) \mathrm{C}$ chemokine domain presentation. JBiol Chem 275: 37813786.

Fong AM, Robinson LA, Steeber DA, Tedder TF, Yoshie O, Imai T, Patel DD (1998). Fractalkine and CX3CR1 mediate a novel mechanism of leukocyte capture, firm adhesion, and activation under physiologic flow. J Exp Med 188: $1413-1419$.

Foussat A, Bouchet-Delbos L, Berrebi D, Durand-Gasselin I, Coulomb-L'Hermine A, Krzysiek R, Galanaud P, Levy Y, Emilie D (2001). Deregulation of the expression of the fractalkine/fractalkine receptor complex in HIV-1infected patients. Blood 98: 1678-1686.

Foussat A, Coulomb-L'Hermine A, Gosling J, Krzysiek R, Durand-Gasselin I, Schall T, Balian A, Richard Y, Galanaud P, Emilie D (2000). Fractalkine receptor expression by $\mathrm{T}$ lymphocyte subpopulations and in vivo production of fractalkine in human. Eur J Immunol 30: 87-97. 
Fraticelli P, Sironi M, Bianchi G, D’Ambrosio D, Albanesi C, Stoppacciaro A, Chieppa M, Allavena P, Ruco L, Girolomoni G, et al (2001). Fractalkine (CX3CL1) as an amplification circuit of polarized Th1 responses. J Clin Invest 107: 1173-1181.

Fujimoto K, Imaizumi $\mathrm{T}$, Yoshida $\mathrm{H}$, Takanashi $\mathrm{S}$, Okumura K, Satoh K (2001). Interferon-gamma stimulates fractalkine expression in human bronchial epithelial cells and regulates mononuclear cell adherence. Am J Respir Cell Mol Biol 25: 233-238.

Furuichi K, Wada T, Iwata Y, Sakai N, Yoshimoto K, Shimizu M, Kobayashi K, Takasawa K, Kida H, Takeda S, et al (2001). Upregulation of fractalkine in human crescentic glomerulonephritis. Nephron 87: 314-320.

Gabuzda D, He J, Ohagen A, Vallat A (1998). Chemokine receptors in HIV-1 infection of the central nervous system. Immunology 10: 203-213.

Gabuzda D, Wang J (1999). Chemokine receptors and virus entry in the central nervous system. J NeuroVirol 5: 643658.

Gabuzda D, Wang J (2000). Chemokine receptors and mechanisms of cell death in HIV neuropathogenesis. J NeuroVirol 6 (Suppl 1): S24-S32.

Gabuzda D, Wang J, Gorry P (2002). HIV-1-associated dementia. In: Chemokines and the nervous system. Ransohoff RM, Suzuki K, Proudfoot AEI, Hickey WF, Harrison JK (eds). Elsevier Science: Amsterdam, pp 345-360.

Garaci E, Caroleo MC, Aloe L, Aquaro S, Piacentini M, Costa N, Amendola A, Micera A, Calio R, Perno CF, Levi-Montalcini R (1999). Nerve growth factor is an autocrine factor essential for the survival of macrophages infected with HIV. Proc Natl Acad Sci USA 96: 1401314018.

Garcia GE, Xia Y, Chen S, Wang Y, Ye RD, Harrison JK, Bacon KB, Zerwes HG, Feng L (2000). NF-kappaBdependent fractalkine induction in rat aortic endothelial cells stimulated by IL-1beta, TNF-alpha, and LPS. J Leukoc Biol 67: 577-584.

Garton KJ, Gough PJ, Blobel CP, Murphy G, Greaves DR, Dempsey PJ, Raines EW (2001). Tumor necrosis factor-alpha-converting enzyme (ADAM17) mediates the cleavage and shedding of fractalkine (CX3CL1). J Biol Chem 276: 37993-38001.

Gelbard H, Nottet H, Dzenko K, Jett M, Genis P, White R, Wang L, Choi Y-B, Zhang D, Lipton S, et al (1994). Platelet-activating factor: a candidate human immunodeficiency virus type-1 infection neurotoxin. J Virol 68: 4628-4635.

Gelbard HA, Epstein LG (1995). HIV-1 encephalopathy in children. Curr Opin Pediatr 7: 655-662.

Gendelman H, Persidsky Y, Ghorpade A, Limoges J, Stins M, Fiala M, Morrisett R (1997). The neuropathogenesis of AIDS dementia complex. AIDS 11: S35-S45.

Gendelman HE (1997). The neuropathogenesis of HIV-1 dementia. In: The neurology of AIDS. Gendelman HE, Lipton SA, Epstein LG, Swindells S (eds). Chapman and Hall: New York, pp 1-10.

Genis P, Jett M, Bernton E, Boyle T, Gelbard H, Dzenko K, Keane R, Resnick L, Mizrachi Y, Volsky D, et al (1992). Cytokines and arachidonic metabolites produced during human immunodeficiency virus (HIV)infected macrophage-astroglia interactions: implications for the neuropathogenesis of HIV disease. J Exp Med 176: 1703-1718.
Ghorpade A, Xia MQ, Hyman BT, Persidsky Y, Nukuna A, Bock P, Che M, Limoges J, Gendelman HE, Mackay CR (1998). Role of the $\beta$-chemokine receptors CCR3 and CCR5 in human immunodeficiency virus type 1 infection of monocytes and microglia. J Virol 72: 3351-3361.

Giulian D, Noonan C, Vaca K (1990). HIV-1 infected mononuclear phagocytes release neurotoxins. Science 250: 1593-1595.

Giulian D, Yu J, Xia L, Tom D, Li J, Lin SN, Schwarz R, Noonan C (1996). Study of receptor-mediated neurotoxins released by HIV-1 infected mononuclear phagocytes found in human brain. J Neurosci 16: 3139-3153.

Glass JD, Fedor H, Wesselingh SL, McArthur JC (1995). Immunocytochemical quantitation of human immunodeficiency virus in the brain: correlations with dementia. Ann Neurol 38: 755-762.

Gleichmann M, Gillen C, Czardybon M, Bosse F, GreinerPetter R, Auer J, Muller HW (2000). Cloning and characterization of SDF-1gamma, a novel SDF-1 chemokine transcript with developmentally regulated expression in the nervous system. Eur J Neurosci 12: 1857-1866.

Goda S, Imai T, Yoshie O, Yoneda O, Inoue $\mathrm{H}$, Nagano Y, Okazaki T, Imai H, Bloom ET, Domae N, Umehara $\mathrm{H}$ (2000). CX3C-chemokine, fractalkine-enhanced adhesion of THP-1 cells to endothelial cells through integrindependent and -independent mechanisms. J Immunol 164: 4313-4320.

Greaves DR, Hakkinen T, Lucas AD, Liddiard K, Jones E, Quinn CM, Senaratne J, Green FR, Tyson K, Boyle J, et al (2001). Linked chromosome 16q13 chemokines, macrophage-derived chemokine, fractalkine, and thymus- and activation-regulated chemokine are expressed in human atherosclerotic lesions. Arterioscler Thromb Vasc Biol 21: 923-929.

Greaves DR, Gordon S (2001). Immunity, atherosclerosis and cardiovascular disease. Trends Immunol 22: 180181.

Harrison JK, Fong AM, Swain PA, Chen S, Yu YR, Salafranca MN, Greenleaf WB, Imai T, Patel DD (2001). Mutational analysis of the fractalkine chemokine domain: basic amino acid residues differentially contribute to CX3CR1 binding, signaling, and cell adhesion. J Biol Chem 276: 8.

Harrison JK, Jiang Y, Chen S, Xia Y, Maciejewski D, McNamara RK, Streit, WJ, Salafranca MN, Adhikari S, Thompson DA, et al (1998). Role for neuronally derived fractalkine in mediating interactions between neurons and CX3CR1-expressing microglia. Proc Natl Acad Sci USA 95: 10896-10901.

Haskell CA, Cleary MD, Charo IF (1999). Molecular uncoupling of fractalkine-mediated cell adhesion and signal transduction. Rapid flow arrest of CX3CR1-expressing cells is independent of G-protein activation. J Biol Chem 274: 10053-10058.

Haskell CA, Cleary MD, Charo IF (2000). Unique role of the chemokine domain of fractalkine in cell capture. Kinetics of receptor dissociation correlate with cell adhesion. J Biol Chem 275: 34183-34189.

Haskell CA, Hancock WW, Salant DJ, Gao W, Csizmadia V, Peters W, Faia K, Fituri O, Rottman JB, Charo IF (2001). Targeted deletion of CX(3)CR1 reveals a role for fractalkine in cardiac allograft rejection. J Clin Invest 108: $679-688$.

He J, Chen Y, Farzan M, Choe H, Ohagen A, Gartner S, Busciglio J, Yang X, Hofmann W, Newman W, 
et al (1997). CCR3 and CCR5 are co-receptors for HIV-1 infection of microglia. Nature 385: 645-649.

Hesselgesser J, Horuk R (1999). Chemokine and chemokine receptor expression in the central nervous system. J NeuroVirol 5: 13-26.

Heyes MP, Brew BB, Martin A, Price RW, Salazar A, Sidtis JJ, Yergey JA, Mouradian MM, Sadler AE, Keilp J, et al (1991). Quinolinic acid in cerebrospinal fluid and serum in HIV-1 infection: relationship to clinical and neurological status. Ann Neurol 29: 202-209.

Hoover DM, Mizoue LS, Handel TM, Lubkowski J (2000). The crystal structure of the chemokine domain of fractalkine shows a novel quaternary arrangement. J Biol Chem 275: 23187-23193.

Horuk R, Martin A, Hesselgesser J, Hadley T, Lu ZH, Wang ZX, Peiper SC (1996). The Duffy antigen receptor for chemokines: structural analysis and expression in the brain. J Leukoc Biol 59: 29-38.

Hughes PM, Botham MS, Frentzel S, Mir A, Perry VH (2002). Expression of fractalkine (CX3CL1) and its receptor, CX3CR1, during acute and chronic inflammation in the rodent CNS. Glia 37: 314-327.

Iismaa T, Biden T, Shine J (1995). G protein-coupled receptors. RG Landes: Austin, TX.

Imai T, Hieshima K, Haskell C, Baba M, Nagira M, Nishimura M, Kakizaki M, Takagi S, Nomiyama H, Schall TJ, Yoshie O (1997). Identification and molecular characterization of fractalkine receptor CX3CR1, which mediates both leukocyte migration and adhesion. Cell 91: $521-530$.

Imaizumi T, Matsumiya T, Fujimoto K, Okamoto K, Cui X, Ohtaki U, Hidemi Yoshida, Satoh K (2000). Interferongamma stimulates the expression of CX3CL1/fractalkine in cultured human endothelial cells. Tohoku J Exp Med 192: $127-139$.

Inngjerdingen M, Damaj B, Maghazachi AA (2001). Expression and regulation of chemokine receptors in human natural killer cells. Blood 97: 367-375.

Janssen R, Cornblath D, Epstein L, Foa R, McArthur J, Price R, Asbury A, Beckett A, Benson D, Bridge T, et al (1991). Nomenclature and research case definitions for neurological manifestations of human immunodeficiency virus type 1 (HIV-1) infection. Neurology 41: 778785.

Jiang Z, Piggee C, Heyes MP, Murphy C, Quearry B, Bauer M, Zheng J, Gendelman HE, Markey SP (2001). Glutamate is a mediator of neurotoxicity in secretions of activated HIV- 1-infected macrophages. J Neuroimmunol 117: 97107.

Jung S, Aliberti J, Graemmel P, Sunshine MJ, Kreutzberg GW, Sher A, Littman DR (2000). Analysis of fractalkine receptor CX(3)CR1 function by targeted deletion and green fluorescent protein reporter gene insertion. Mol Cell Biol 20: 4106-4114.

Kansra V, Groves C, Gutierrez-Ramos JC, Polakiewicz RD (2001). Phosphatidylinositol 3-kinase-dependent extracellular calcium influx is essential for CX(3)CR1mediated activation of the mitogen-activated protein kinase cascade. J Biol Chem 276: 31831-31838.

Karpus WJ (2001). Chemokines and central nervous system disorders. J NeuroVirol 7: 493-500.

Kaul M, Lipton SA (1999). Chemokines and activated macrophages in HIV gp120-induced neuronal apoptosis [In Process Citation]. Proc Natl Acad Sci USA 96: 8212-8216.
Kelder W, McArthur JC, Nance-Sproson T, McClernon D, Griffin DE (1998). $\beta$-Chemokines MCP-1 and RANTES are selectively increased in cerebrospinal fluid of patients with human immunodeficiency virus-associated dementia. Ann Neurol 44: 831-835.

Kerr SJ, Armati PJ, Guillemin GJ, Brew BJ (1998). Chronic exposure of human neurons to quinolinic acid results in neuronal changes consistent with AIDS dementia complex. AIDS 12: 355-363.

Kerschensteiner M, Gallmeier E, Behrens L, Leal VV, Misgeld T, Klinkert WE, Kolbeck R, Hoppe E, OropezaWekerle RL, Bartke I, et al (1999). Activated human $\mathrm{T}$ cells, B cells, and monocytes produce brain-derived neurotrophic factor in vitro and in inflammatory brain lesions: a neuroprotective role of inflammation? J Exp Med 189: 865-870.

Kitai R, Zhao ML, Zhang N, Hua LL, Lee SC (2000). Role of MIP-1beta and RANTES in HIV-1 infection of microglia: inhibition of infection and induction by IFNbeta. J Neuroimmunol 110: 230-239.

Klein R, Williams K, Alvarez-Hernandez X, Westmoreland S, Force T, Lackner A, Luster A (1999). Chemokine receptor expression and signaling in macaque and human fetal neurons and astrocytes: implications for the neuropathogenesis of AIDS. J Immunol 163: 1636-1646.

Koenig S, Gendelman HE, Orenstein JM, Canto MCD, Pezeshkpour GH, Yungbluth M, Janotta F, Aksamit A, Martin MA, Fauci AS (1986). Detection of AIDS virus in macrophages in brain tissue from AIDS patients with encephalopathy. Science 233: 1089-1093.

Kornbluth RS, Kee K, Richman DD (1998). CD40 ligand (CD154) stimulation of macrophages to produce HIV-1suppressive beta-chemokines. Proc Natl Acad Sci USA 95: 5205-5210.

Krebs FC, Ross H, McAllister J, Wigdahl B (2000). HIV-1associated central nervous system dysfunction. Adv Pharmacol 49: 315-385.

Kullander K, Kylberg A, Ebendal T (1997). Specificity of neurotrophin-3 determined by loss-of-function mutagenesis. J Neurosci Res 50: 496-503.

Kutsch O, Oh J, Nath A, Benveniste EN (2000). Induction of the chemokines interleukin-8 and IP-10 by human immunodeficiency virus type 1 tat in astrocytes. J Virol 74: 9214-9221.

Lavi E, Strizki JM, Ulrich AM, Zhang W, Fu L, Wang Q, O’Connor M, Hoxie JA, Gonzalez-Scarano F (1997). CXCR-4 (fusin), a co-receptor for the type 1 human immunodeficiency virus (HIV-1) is expressed in the human brain in a variety of cell types, including microglia and neurons. Am J Pathol 151: 1035-1042.

Letendre SL, Lanier ER, McCutchan JA (1999). Cerebrospinal fluid beta chemokine concentrations in neurocognitively impaired individuals infected with human immunodeficiency virus type 1. J Infect Dis 180: 310-319.

Lopez A, Bauer MA, Erichsen DA, Peng H, Gendelman L, Shibata A, Gendelman HE, Zheng J (2001). The regulation of neurotrophic factor activities following HIV-1 infection and immune activation of mononuclear phagocytes. Paper presented at the 31st Annual Meeting of the Society for Neuroscience, San Diego, California, November 10-15.

Lopez-Ilasaca M (1998). Signaling from G-protein coupled receptors to mitogen activated protein (MAP) kinase cascades. Biochemical Pharmacol 56: 269-277. 
Lopez-Illasaca M, Crespo P, Pellici PG, Gutkind JS, Wetzker $R$ (1997). Linkage of $G$ protein-coupled receptors to the MAPK signaling pathway through Pl 3-kinase $\gamma$. Science 275: 394-397.

Loy R, Taglialatela G, Angelucci L, Heyer D, Perez-Polo $\mathrm{R}$ (1994). Regional CNS uptake of blood-borne nerve growth factor. J Neurosci Res 39: 339-346.

Lucas AD, Chadwick N, Warren BF, Jewell DP, Gordon S, Powrie F, Greaves DR (2001). The transmembrane form of the CX3CL1 chemokine fractalkine is expressed predominantly by epithelial cells in vivo. Am J Pathol 158: 855-866.

Luster AD (1998). Chemokines-chemotactic cytokines that mediate inflammation. $N$ Engl J Med 338: 436-445.

Ma M, Geiger JD, Nath A (1994). Characterization of a novel binding site for the human immunodeficiency virus type 1 envelope protein gp120 on human fetal astrocytes. J Virol 68: 6824-6828.

Maciejewski-Lenoir D, Chen S, Feng L, Maki R, Bacon KB (1999). Characterization of fractalkine in rat brain cells: migratory and activation signals for CX3CR-1expressing microglia. J Immunol 163: 1628-1635.

Mackay CR (1996). Chemokine receptors and T cell chemotaxis. J Exp Med 184: 799-802.

Mallat M, Houlgatte R, Brachet P, Prochiantz A (1989). Lipopolysaccharide-stimulated rat brain macrophages release NGF in vitro. Dev Biol 133: 309-311.

Marder K, Albert S, Dooneief G, Stern Y, Ramachandran G, Epstein L (1996). Clinical confirmation of the american academy of neurology algorithm for HIV-1-associated cognitive/motor disorder. Neurology 47: 1247-1253.

Masliah E (1996). In vivo modeling of HIV-1 mediated neurodegeneration. Am J Pathol 149: 745-750.

Masliah E, DeTeresa RM, Mallory ME, Hansen LA (2000). Changes in pathological findings at autopsy in AIDS cases for the last 15 years. Aids 14: 69-74.

McArthur JC, Sacktor N, Selnes O (1999). Human immunodeficiency virus-associated dementia. Semin Neurol 19: $129-150$.

McDermott DH, Halcox JP, Schenke WH, Waclawiw MA, Merrell MN, Epstein N, Quyyumi AA, Murphy PM (2001). Association between polymorphism in the chemokine receptor CX3CR1 and coronary vascular endothelial dysfunction and atherosclerosis. Circ Res 89: 401-407.

Meucci O, Fatatis A, Simen AA, Bushell TJ, Gray PW, Miller RJ (1998). Chemokines regulate hippocampal neuronal signaling and gp120 neurotoxicity. Proc Natl Acad Sci 95: $14500-14505$.

Meucci O, Fatatis A, Simen AA, Miller RJ (2000). Expression of CX3CR1 chemokine receptors on neurons and their role in neuronal survival. Proc Natl Acad Sci USA 97: 8075-8080.

Miller RJ, Meucci O (1999). AIDS and the brain: is there a chemokine connection? Trends Neurosci 22: 471-479.

Minami M, Satoh M (2000). Chemokines as mediators for intercellular communication in the brain (in Japanese). Nippon Yakurigaku Zasshi 115: 193-200.

Miwa T, Furukawa S, Nakajima K, Furukawa Y, Kohsaka S (1997). Lipopolysaccharide enhances synthesis of brainderived neurotrophic factor in cultured rat microglia. J Neurosci Res 50: 1023-1029.

Mizoue LS, Bazan JF, Johnson EC, Handel TM (1999). Solution structure and dynamics of the CX3C chemokine domain of fractalkine and its interaction with an
N-terminal fragment of CX3CR1. Biochemistry 38: 1402-1414.

Mizoue LS, Sullivan SK, King DS, Kledal TN, Schwartz TW, Bacon KB, Handel TM (2001). Molecular determinants of receptor binding and signaling by the CX3C chemokine fractalkine. J Biol Chem 276: 33906-33914.

Mollace V, Nottet HS, Clayette P, Turco MC, Muscoli C, Salvemini D, Perno CF (2001). Oxidative stress and neuroAIDS: triggers, modulators and novel antioxidants. Trends Neurosci 24: 411-416.

Moses AV, Bloom FE, Pauza CD, Nelson JA (1993). HIV infection of human brain capillary endothelial cells occurs via a CD4/galactosylceramide-independent mechanism. Proc Natl Acad Sci USA 90: 10474-10478.

Nagasawa T, Hirota S, Tachibana K, Takakura N, Nishikawa S, Kitamura Y, Yoshida N, Kikutani H, Kishimoto $\mathrm{T}$ (1996). Defects of B-cell lymphopoiesis and bone-marrow myelopoiesis in mice lacking the CXC chemokine PBSF/SDF-1. Nature 382: 635-638.

Nath A, Geiger J (1998). Neurobiological aspects of human immunodeficiency virus infection: neurotoxic mechanisms. Prog Neurobiol 54: 19-33.

Nath A, Hartloper V, Furer M, Fowke KR (1995). Infection of human fetal astrocytes with HIV-1: viral tropism and the role of cell to cell contact in viral transmission. J Neuropathol Exp Neurol 54: 320-330.

Navia BA, Cho ES, Petito CK, Price RW (1986). The AIDS dementia complex: II. Neuropathology. Ann Neurol 19: 525-535.

Nishiyori A, Minami M, Ohtani Y, Takami S, Yamamoto J, Kawaguchi N, Kume T, Akaike A, Satoh M (1998). Localization of fractalkine and CX3CR1 mRNAs in rat brain: does fractalkine play a role in signaling from neuron to microglia? FEBS Lett 429: 167-172.

Peng H, Huang Y, Erichsen D, Zheng J (2002). HIV-1 gp120 and SDF1- $\alpha$ inhibit neural progenitor cell proliferation: links to HIV-1 associated dementia. Paper presented at The 32rd Annual Meeting of Society for Neuroscience, Orlando, Florida, November 2-7.

Pereira CF, Middel J, Jansen G, Verhoef J, Nottet HS (2001). Enhanced expression of fractalkine in HIV-1 associated dementia. J Neuroimmunol 115: 168-175.

Perno CF, Crowe SM, Kornbluth RS (1997). A continuing enigma: the role of cells of macrophage lineage in the development of HIV disease. J Leukoc Biol 62: 1-3.

Persidsky Y (1999). Model systems for studies of leukocyte migration across the blood-brain barrier. J NeuroVirol 5: 579-590.

Persidsky Y, Ghorpade A, Rasmussen J, Limoges J, Liu XJ, Stins M, Fiala M, Way D, Kim KS, Witte MH, et al (1999). Microglial and astrocyte chemokines regulate monocyte migration through the blood-brain barrier in human immunodeficiency virus-1 encephalitis. Am J Pathol 155: 1599-1611.

Pulliam L, Herndier BG, Tang NM, McGrath MS (1991). Human immunodeficiency virus-infected macrophages produce soluble factors that cause histological and neurochemical alterations in cultured human brains. J Clin Invest 87: 503-512.

Ranki A, Nyberg M, Ovod V, Haltia M, Elovaara I, Raininko R, Haapasalo H, Krohn K (1995). Abundant expression of HIV Nef and Rev proteins in brain astrocytes in vivo is associated with dementia. AIDS 9: 1001-1008.

Ransohoff $\mathrm{R}$ (1997). Chemokines in neurological disease models: correlation between chemokine expression 
patterns and inflammatory pathology. J Leukoc Biol 62: 645-652.

Ransohoff RM (1998). Chemokines and CNS Inflammation. Neurotransm 14: 3-12.

Rappaport J, Joseph J, Croul S, Alexander G, Del Valle L, Amini S, Khalili K (1999). Molecular pathway involved in HIV-1-induced CNS pathology: role of viral regulatory protein, Tat. J Leukoc Biol 65: 458-465.

Raychaudhuri SP, Jiang WY, Farber EM (2001). Cellular localization of fractalkine at sites of inflammation: antigen-presenting cells in psoriasis express high levels of fractalkine. Br J Dermatol 144: 1105-1113.

Rocamora N, Pascual M, Acsady L, Lecea LD, Freund TF (1996). Expression of NGF and NT3 mRNAs hippocampal interneurons innervated by the GABAergic septohippocampal pathway. J Neurosci 16: 3991-4004.

Ruth JH, Volin MV, Haines GK 3rd, Woodruff DC, Katschke KJ, Jr, Woods JM, Park CC, Morel JC, Koch AE (2001). Fractalkine, a novel chemokine in rheumatoid arthritis and in rat adjuvant-induced arthritis. Arthritis Rheum 44: 1568-1581.

Saad B, Constam D, Ortmann R, Moos M, Fontana A, Schachner M (1991). Astrocyte-derived TGF- $\beta 2$ and NGF differentially regulate neural recognition molecule expression by cultured astrocytes. J Cell Biol 115: 473484.

Sanders VJ, Pittman CA, White MG, Wang G, Wiley CA, Achim CL (1998). Chemokines and receptors in HIV encephalitis. AIDS 12: 1021-1026.

Schwaeble WJ, Stover CM, Schall TJ, Dairaghi DJ, Trinder PK, Linington C, Iglesias A, Schubart A, Lynch NJ, Weihe E, Schafer MK (1998). Neuronal expression of fractalkine in the presence and absence of inflammation. FEBS Lett 439: 203-207.

Sebire G, Emilie D, Wallon C, Hery C, Devergne O, Delfraissy J-F, Galanaud P, Tardieu M (1993). In vitro production of IL-6, IL- $1 \beta$, and tumor necrosis factor- $\alpha$ by human embryonic microglial and neural cells. J Immunol 150: 1517-1523.

Shieh JTC, Albright AV, Sharron M, Gartner S, Strizki J, Doms RW, Gonzalez-Scarano F (1998). Chemokine receptor utilization by human immundeficiency virus type 1 isolates that replicate in microglia. J Virol 72: 4243-4249.

Strizki JM, Albright AV, Sheng H, O'Connor M, Perrin L, Gonzalez-Scarano F (1996). Infection of primary human microglia and monocyte-derived macrophages with human immunodeficiency virus type 1 isolates: evidence of differential tropism. J Virol 70: 7654-7662.

Tong N, Perry SW, Zhang Q, James HJ, Guo H, Brooks A, Bal H, Kinnear SA, Fine S, Epstein LG, et al (2000). Neuronal fractalkine expression in HIV-1 encephalitis: roles for macrophage recruitment and neuroprotection in the central nervous system. J Immunol 164: 1333-1339.

Tornatore C, Nath A, Amemiya K, Major EO (1991). Persistent human immunodeficiency virus type 1 infection in human fetal glial cells reactivated by T-cell factor(s) or by the cytokines tumor necrosis factor alpha and interleukin-1 beta. J Virol 65: 6094-6100.

Tsou CL, Haskell CA, Charo IF (2001). Tumor necrosis factor-alpha-converting enzyme mediates the inducible cleavage of fractalkine. J Biol Chem 276: 4462244626.

Vallat A-V, Girolami UD, He J, Mhashikar A, Marasco W, Shi B, Gray F, Bell J, Keohane C, Smith TW, Gabuzda D (1998). Localization of HIV-1 co-receptors CCR5 and
CXCR4 in the brain of children with AIDS. Am J Pathol 152: $167-178$.

van der Meer P, Ulrich AM, Gonzalez-Scarano F, Lavi E (2000). Immunohistochemical analysis of CCR2, CCR3, CCR5, and CXCR4 in the human brain: potential mechanisms for HIV dementia. Exp Mol Pathol 69: 192-201.

Vicenzi E, Alfano M, Ghezzi S, Gatti A, Veglia F, Lazzarin A, Sozzani S, Mantovani A, Poli G (2000). Divergent regulation of HIV-1 replication in PBMC of infected individuals by CC chemokines: suppression by RANTES, MIP-1alpha, and MCP-3, and enhancement by MCP-1. J Leukoc Biol 68: 405-412.

Volin MV, Woods JM, Amin MA, Connors MA, Harlow LA, Koch AE (2001). Fractalkine: a novel angiogenic chemokine in rheumatoid arthritis. Am J Pathol 159: 1521-1530.

Wiley CA (1995). Quantitative neuropathologic assessment of HIV-1 encephalitis. Curr Top Microbiol Immunol 202: $55-61$.

Wiley CA, Achim C (1994). Human immunodeficiency virus encephalitis is the pathological correlate of dementia in acquired immunodeficiency syndrome. Ann Neurol 36: 673-676.

Wiley CA, Masliah E, Morey M, Lemere C, Teresa R, Grafe M, Hansen L, Terry R (1991). Neocortical damage during HIV infection. Ann Neurol 29: 651-657.

Wiley CA, Schrier RD, Nelson JA, Lampert PW, Oldstone MBA (1986). Cellular localization of human immunodeficiency virus infection within the brains of acquired immune deficiency syndrome patients. Proc Natl Acad SCi USA 83: 7089-7093.

Wu DT, Woodman SE, Weiss JM, McManus CM, D’Aversa TG, Hesselgesser J, Major EO, Nath A, Berman JW (2000). Mechanisms of leukocyte trafficking into the CNS. J NeuroVirol 6(Suppl 1): S82-S85.

Yoshida H, Imaizumi T, Fujimoto K, Matsuo N, Kimura K, Cui X, Matsumiya T, Tanji K, Shibata T, Tamo W, et al (2001). Synergistic stimulation, by tumor necrosis factor-alpha and interferon-gamma, of fractalkine expression in human astrocytes. Neurosci Lett 303: 132136.

Zheng J, Bauer M, Cotter RL, Ryan LA, Lopez A, Williams C, Ghorpade A, Gendelman HE (2000). Fractalkine mediated macrophage activation by neuronal injury: relevance for HIV-1 associated dementia. Paper presented at The 30th Annual Meeting of Society for Neuroscience, New Orleans, Louisiana, November 4-9.

Zheng J, Gendelman HE (1997). The HIV-1 associated dementia complex: a metabolic encephalopathy fueled by viral replication in mononuclear phagocytes. Curr Opin Neurol 10: 319-325.

Zheng J, Lopez A, Erichsen D, Peng H, Bauer M, Williams C, Morgello S, Ghorpade A, Gendelman HE, Cotter RL, Ryan LA (2002). Neuronal fractalkine: regulation of macrophage activation and inflammatory factor production during HIV-1 associated dementia. J Immunol Submitted.

Zheng J, Niemann D, Bauer M, Williams C, Lopez A, Erichsen D, Ryan LA, Cotter RL, Ghorpade A, Swindells S, Gendelman HE (2001). HIV-1 glia interactions in interleukin-8 and growth-related oncogene a secretion, neuronal signaling and demise: relevance for HIV-1associated dementia. Paper presented at The 8th Conference on Retroviruses and Opportunistic Infections, Foundation for Retrovirology and Human Health, Chicago, Illinois, February 4-8. 
Zheng J, Thylin M, Ghorpade A, Xiong H, Persidsky Y, Cotter R, Niemann D, Che M, Zeng Y, Gelbard H, et al (1999). Intracellular CXCR4 signaling, neuronal apoptosis and neuropathogenic mechanisms of HIV-1associated dementia. J Neuroimmunol 98: 185-200.

Zlotnik A, Yoshie O (2000). Chemokines: a new classification system and their role in immunity. Immunity 12: 121-127.
Zou YR, Kottmann AH, Kuroda M, Taniuchi I, Littman DR (1998). Function of the chemokine receptor CXCR4 in haematopoiesis and in cerebellar development. Nature 393: 595-599.

Zujovic V, Benavides J, Vige X, Carter C, Taupin V (2000). Fractalkine modulates TNF-alpha secretion and neurotoxicity induced by microglial activation [In Process Citation]. Glia 29: 305-315. 